\title{
Operating Procedures for Conducting Monetary Policy
}

\section{R. Alton Gilbert}

W that determines the nation's monetary policy is the Federal Open Market Committee (FOMC). The FOMC meets several times each year, specifying targets for the federal funds rate and money growth over the period until the next scheduled meeting. "Twice each year, in February and July, the FOMC also announces its annual objectives for growth of the monetary aggregates. The Committee began setting targets for the growth rates of the monetary aggregates in 1970 , because of a growing recognition of the effects of money growth on total spending and inflation. The FOMC also gives some weight to the short-run stability of interest rates, expressed as ranges for the federal funds rate.

After the FOMC determines the objectives for monetary policy, the task of implementing the policy is delegated to the staff of the Open Market Desk at the

R. Alton Gilbert is an assistant vice president at the Federal Reserve Bank of St. Louis. Paul G. Christopher provided research assistance.

The FOMC consists of the seven members of the Federat Reserve Board of Governors and five of the 12 Federal Reserve Bank presidents. The Chairman of the Board of Governors is, by tradition, chairman of the FOMC. The president of the Federal Reserve Bank of New York is a permanent member of the FOMC and, also by tradition, its vice chairman. The four remaining memberships rotate among the presidents and are held for one-year terms beginning March 1 of each year. All Federal Reserve Bank presidents attend the meetings and present their views, but only those who are members of the FOMC cast votes. The FOMC currently has eight scheduled meetings each year, but may have a conference-call meeting to reevaluate monetary policy at any time.
Federal Reserve Bank of New York. The Open Market Desk does this by buying and selling federal government securities for the Federal Reserve System. It increases reserves of the banking system by buying additional government securities and decreases reserves by selling securities.

The FOMC's instructions to the Open Market Desk also include a procedure that it should use to implement monetary policy. This paper identifies three distinct procedures used by the Open Market Desk since 1970. The purpose of the paper is to describe the mechanics of these three operating procedures, identifying the steps followed by the Open Market Desk in determining the amount of reserves to supply through open market operations.

The first procedure, which was used in the 1970s, involved targeting on the federal funds rate; the Open Market Desk would supply the level of reserves necessary to keep the federal funds rate within ranges spem cified by the FOMC for periods between meetings. The next procedure, used during the three years ending in October 1982, involved targeting on levels of nonborrowed reserves (reserves other than those borrowed from Federal Reserve Banks); these were based on the FOMC objectives for the money stock. This procedure allowed for wider short-run fluctuations in the federal funds rate. Under the final procedure, in effect since October 1982, the objective of the Open Market Desk in each reserve maintenance period is to keep the total of reserves borrowed by depository institutions from Federal Reserve Banks near some desired level. The 
desired level of borrowings reflects the desired degree of reserve restraint specified by the FOMC at each meeting.

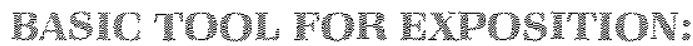

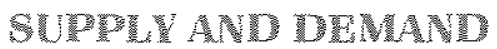 FOR TSERES}

The mechanics of the implementation of monetary policy under the three operating procedures can be described by analyzing the market for total reserves of depository institutions. These reserves include currency that depository institutions hold in their vaults and reserve balances they hold at Federal Reserve Banks. Depository instinutions hold reserves to facilitate their customers' transactions and to meet reserve requirements imposed by the Federal Reserve. The required reserves are based on the amount and composition of their deposit liabilities.

Because they earn no interest on reserves, there is an opportunity cost for depository institutions to hold them. The opportunity cost is identified in this paper as the federal funds rate, the interest rate that depository institutions charge each other for lending reserves." If a depository institution must increase its reserves, it borrows at the federal funds rate; if it can reduce its reserves, it lends at the federal funds rate.

In the three figures used in this paper, the demand for reserves by depository institutions is drawn as a function of the federal funds rate. Reserve requirements on those deposits included in the money stock create a close relationship between the demand for money by the public and the demand for reserves by depository institutions. The demand for money is assumed to be a function of total spending in the economy and interest rates. Various influences can cause shifts in the demand curve for reserves. A change in total spending in the economy, which influences the demand for money, would cause the demand curve for reserves to shift. Shifts in the demand for reserves could also reflect changes in the random component of money demand, a change in the average reserve requirement on deposit liabilities included in the

\footnotetext{
2Federal funds brokers facilitate the operation of the federal funds market. These brokers receive orders from depository institutions located throughout the nation to lend or borrow reserves, and the brokers match lenders and borrowers ai mutualy agreeable interest rates. Most of the transactions through the federal funds market involve borrowing and lending reserves for one day. The transfers of reserves to borrowers are made the same day through wire transfer systems, including the Fed Wire of the Federal Reserve System.
}

money stock or a change in the demand for excest reserves.

The factors that influence the supply of reserves car be analyzed by considering separately the determinants of borrowed and nonborrowed reserves. Nonbortowed reserves (NBR) are determined by the open market operations of the Open Market Desk.

The amount of reserves borrowed from Federal Reserve Banks is influenced by the spread between the federal funds rate and the discount rate, and by the conditions set by the Federal Reserve for permitting depository institutions to borrow reserves. If the discount rate is above the federal funds rate, the amount of reserves borrowed from Federal Reserve Banks tends to be relatively low and insensitive to small changes in the federal funds rate. The supply curve for reserves reflects this observation. The supply curve is drawn as a vertical line from the level of NBR labeled $N$ in the figures) up to the level on the vertical axis at which the federal funds rate equals the discount rate, indicated as $r_{\mathrm{f}}^{\ddagger}=\Gamma_{\mathrm{a}}$.

The shape of the supply curve in the range in which the federal funds rate exceeds the discount rate depends on the conditions under which Federal Reserve Banks permit depository institutions to borrow reserves. If the Federal Reserve did not set limits on borrowings, no institution would pay more than the discount rate to borrow reserves in the federal funds market. In that case, the relevant supply curve in the range of the horizontal axis above NBR would be horizontal at the level of the federal funds rate equal to the discount rate.

The relevant supply curve is not horizontal however; instead, it slopes upward, like the curves in the three figures labelled $S_{1}, S_{2}$ and $S_{3}$. The shape of each supply curve reflects a method of nonprice rationing of borrowed reserves among depository institutions. These supply curves differ only by the amount of NBR; each curve reflects the same method of nonprice rationing of borrowed reserves.

The Federal Reserve rations borrowed reserves by setting limits on the borrowings by each depository institution. These limits are set in terms of (1) the amounts borrowed relative to the required reserves of the depository institution and (2) the frequency and duration of its borrowings. Depository institutions try to avoid exceeding these borrowing limits to ensure that they will have access to credit to cover short-term liquidity requirements. If a depository institution borrows now, it will be subjected to greater administrative pressure to limit its borrowings in the future, when 
the attractiveness of borrowing from the discount window might be greater. Consequently, it takes an increase in the spread between the federal funds rate and the discount rate to induce depository institutions to increase their borrowings from the discount window. The slope of each supply curve reflects this relationship between borrowings and the interest rate spread.

The three figures in this paper illustrate short-run relationships between the supply and demand for reserves. In figure 1, the relevant time period is a oneweek reserve maintenance period. ${ }^{3}$ The relevant time period for figure 2 is a few weeks between FOMC meetings. For figure 3, which illustrates the current operating procedure, the time period is a two-week reserve maintenance period. Reserve maintenance periods were lengthened from one week to two weeks in February 1984, when the Federal Reserve adopted contemporaneous reserve requirements.

Given its shortwrun focus, this paper does not present a complete analysis of the money supply process under each operating procedure. The more limited purpose of this paper is to describe how open market operations are determined under each operating procedure for a given short time period. The following sections indicate how the short-run analysis of each operating procedure would fit into a more complete analysis of the money supply process.

\section{Th

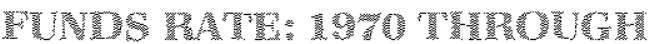

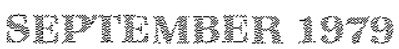

The Federal Reserve attempted to control the money stock during the 1970 s by confining the federal funds rate to relatively narrow ranges, specified at each FOMC meeting. The use of this procedure was based on the assumption of a stable demand function for money. (As indicated previously, money demand is assumed to be a function of interest rates and total spending in the economy. For the period of a few weeks between FOMC meetings, total spending is assumed to be independent of current policy actions.) The Federal Reserve attempted to control the money stock through its influence on interest rates by moving the public up or down its demand for money schedule.

${ }^{3} \mathrm{~A}$ reserve maintenance period is a period over which daily average reserves must equal or exceed daily average required reserves to avoid a penalty for reserve deficiency.

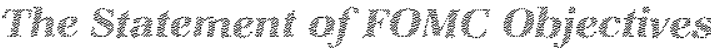

At each meeting, the FOMC stated its growth objectives for the monetary aggregates as ranges from the average of the month before the meeting to the average of the month of the next scheduled meeting. For instance, on September 18, 1979, the last meeting under this operating procedure, the FOMC's objective for M1 was an annual growth rate between 3 percent and 8 percent from August through October.

At each meeting, the FOMC directed the Open Market Desk of the Federal Reserve Bank of New York to keep the federal funds rate within a range of about 50 to 100 basis points until the next meeting, and often specified an initial level for the federal funds rate within the target range. The manager of the Open Market Desk was authorized to let the federal funds rate move toward the top or bottom of the specified range if the money stock was tending to rise above or fall below that desired by the FOMC. The Open Market Desk supplied the amounts of NBR necessary to keep the federal funds rate within the tafget range. Occasionally, the FOMC changed the range for the federal funds rate in conference calls held between scheduled meetings if the money stock was tending to deviate substantially from its objective."

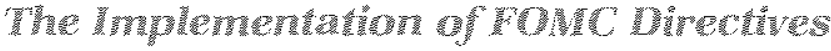

The conduct of monetary policy under this procedure is illustrated in figure 1. At one of its scheduled meetings, the FOMC would specify an initial level for the federal funds rate for the period immediately after the meeting $\left(r_{1}^{2}\right)$ and a range for the rate until the next scheduled meeting $\left(r_{u}-r_{1}\right)$. The Open Market Desk then would adjust NBR to keep the federal funds rate at the initial target rate immediately after the meeting and within the target range until the next meeting. ${ }^{3}$

The time period for the supply and demand curves in figure 1 is one reserve maintenance week. Lagged

4The description of the procedure of targeting on the federal funds rate is based on Lombra and Torto (1975), Holmes and Sternlighi (1977), Wallich and Keir (1979) and Lindsey (1984).

5in examining monetary policy actions, this paper focuses exclusively on the level of NBR. Changes in NBR through open market operations are tine most frequent policy actions by the Federal Reserve. By focusing on the supply of NBA, the paper abstracts from the effects of other policy actions on the supply and demand for reserves. An increase (decrease) in the discount rate would cause the upward-stoping part of the supply curve to rise (fall). Changes in the conditions for borrowing reserves would change the slope of the supply curve in the range in which the federal funds rate exceeds the discount rate. Finally, a change in the reserve requirement ratios would cause the demand curve to shift. 

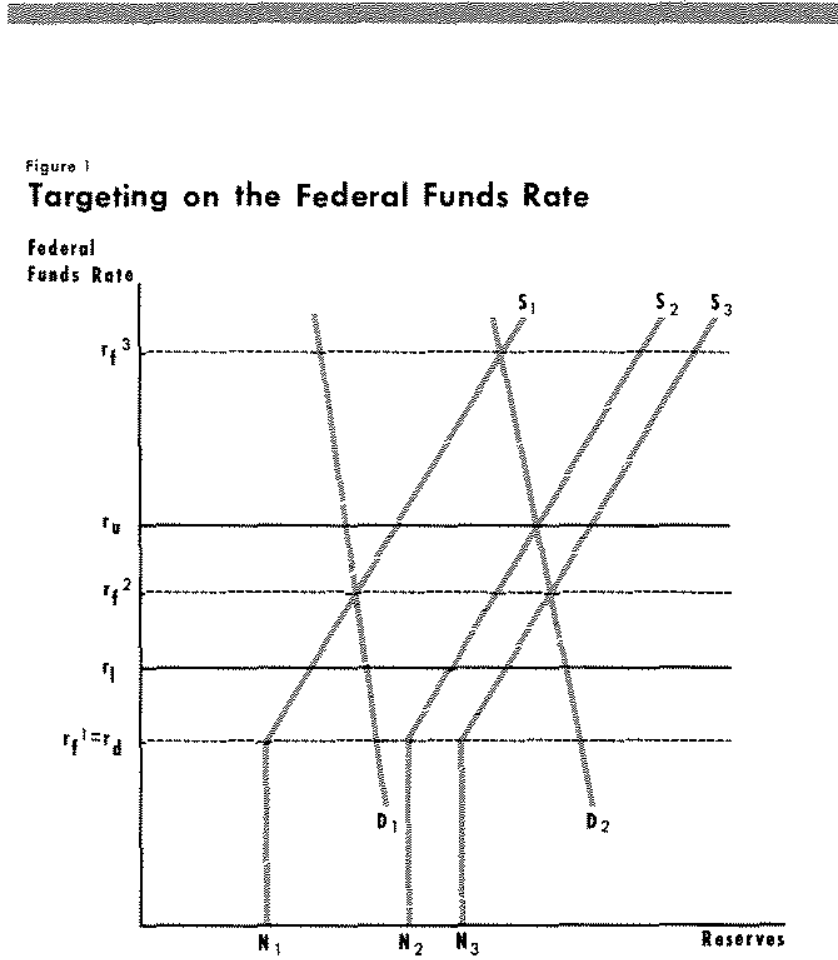

reserve requirements were in effect during the period in which the Open Market Desk targeted on the federal funds rate. Under lagged reserve requirements, required reserves in each maintenance week were predetermined, since they were based on deposits two weeks earlier. Consequently, the demand curves in figure 1 are drawn relatively steep. With required reserves predetermined for each period, the slope of the demand curves reflects the responsiveness of the demand for excess reserves to changes in the levels of the federal funds rate.

The demand for reserves in the first week after the FOMC meeting is denoted by the curve $\mathrm{D}_{1}$. The Open Market Desk would supply NBR equal to $\mathrm{N}_{1}$ to keep the

GUnder lagged reserve requirements, each maintenance period covered seven days ending each Wednesday. Required reserves for each maintenance period were based on deposit liabilities in the maintenance period two weeks earlier. Under the contemporaneous reserve requirements currently in effect, each maintenance period covers 14 days ending every other Wednesday. The required reserves of each depository institution on its checkable deposits are based on its average checkable deposits over a 14-day period ending two days before the end of the current maintenance period. See Gibert and Trebing (1982) for a description of lagged and contemporaneous reserve requirements. federal funds rate at $r_{f}^{2}$. Suppose there was a large increase in the demand for reserves in the second week, represented by the shift in the demand curve from $\mathrm{D}_{1}$ to $\mathrm{D}_{z}$. This increase in the demand for reserves would reflect an increase in the demand for money. To accommodate the increase in the demand for reserves, the Open Market Desk would increase NBR in order to keep the fecteral funds rate in the tafget range set by the FOMC. In figure 1, the Desk would increase the supply of $\mathrm{NBR}$ to $\mathrm{N}_{3}$ to keep the federal funds rate at $r^{2}$.

If, however, the money stock was tending to rise above the desired range of the FOMC, the Desk might have increased NBR to only $\mathrm{N}_{2}$, thus allowing the federal funds rate to rise to the top of the range $\left(r_{u}\right)$. Any authorization for the Open Market Desk to allow an additional rise in the federal funds rate before the next scheduled FOMC meeting would require an FOMC conference call to specify a new range for the federal funds rate.

Discussions of the advantages of this operating procedure usually emphasize how the Federal Reserve could prevent transitory fluctuations in the federal funds rate, while controlling the growth rate of the money supply over a quarter of a year or longer, periods that are relevant for stabilizing economic activity. One cause of transitory fluctuations in the federal funds rate was Open Market Desk errors in measuring NBR in the current week. The Federal Reserve had to estimate several factors that influence NBR, such as balances of the U.S. Treasury at Federal Reserve Banks and Federal Reserve float. If, however, the Federal Reserve made large errors in estimating the current level of NBR, this procedure would offset those errors automatically. For instance, if actual NBR fell below Federal Reserve estimates, the federal funds rate would tend to rise above the target rate, and the Open Market Desk would respond by buying additional securities, thus increasing NBR.

Another type of transitory effect on interest rates would be a transitory shift in the demand for total reserves. The demand for total reserves may shift for various reasons. There may be random fluctuations in the demand for money, average reserve requirements or excess reserves. Under this procedure, the Open Market Desk would offset the effects of such transitory shifts in the demand for reserves by adjusting the level of NBR to keep the federal funds rate unchanged.

The effects of transitory shifts in the demand for total reserves are illustrated in figure 1. The demand for reserves is illustrated by the curve $D_{1}$ in the first 
week after an FOMC meeting, $\mathrm{D}_{2}$ in the second week, and $D_{1}$ again in the third week. If the Open Market Desk kept NBR at $N_{1}$ throughout the three-week period, the federal funds rate would be $r_{r}^{2}$ in week $1, r_{i}^{2}$ in week 2 , and would fall back to $r_{f}^{2}$ again in week 3 The Open Market Desk would avoid these fluctuations in the federal funds rate by accommodating the random fluctuations in demand for reserves. Following this policy of accommodation, NBR would be $N_{1}$ in the first week, $N_{3}$ in the second week, and $N_{1}$ again in the third week.

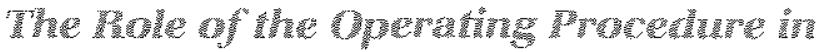

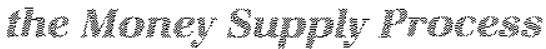

The position of the supply curve for reserves in a given maintenance week had little effect on the quantity of reserves supplied, because required reserves in each week were based on the deposits of two weeks earlier. The position of the supply curve did influence the level of the federal funds rate. In attempting to control the money supply, the Federal Reserve relied on the influence that changes in the federal funds rate would have on other interest rates and the influence of interest rates on the quantity of money demanded in the future. Money demand was assumed to be influenced by lagged values of interest rates. A more thorough treatment of the money supply process under this operating procedure would require an analysis of the effects of policy actions over several reserve maintenance periods. The multiperiod analysis would include changes in the FOMC's federal funds rate objectives in response to deviations of the money stock from desired levels and the lagged effects of changes in interest rates on money demand.

The major problem with this procedure was that, in attempting to stabilize the federal funds rate, the Federal Reserve could miss its targets for the money stock for periods long enough to affect total spending in the economy. A shift in the demand for reserves may have indicated that the federal funds rate must be allowed to change if the Open Market Desk is to supply the level of reserves that is consistent with FOMC objectives for the monetary aggregates. An increase in the demand for reserves may have reflected a rise in the rate of total spending in the economy, which would cause the demand for money to rise. By targeting on a fixed level of the federal funds rate in such circumstances, the Federal Reserve may conduct a procyclical monetary policy - increasing (decreasing) the level of total reserves in response to a rise (fall) in the rate of total spending.

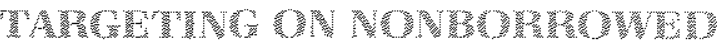

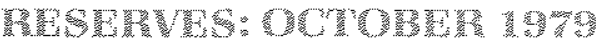

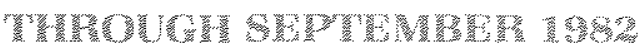

On October 6, 1979, the FOMC abandoned the procedure of targeting on the federal funds rate in favor of an NBR operating procedure. Most of the FOMC members concluded that the degree of monetary control under the previous procedure had become unsatisfactory. They decided to adopt, instead, a procedure in which the objective of open market operations was to supply the amount of reserves consistent with their objectives for money growth, while permitting larger fluctuations in the federal funds rate.

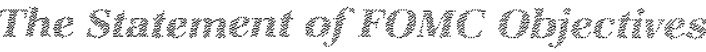

One of the changes adopted at the meeting on October 6, 1979, involved the way the FOMC stated its objectives for the growth of the monetary aggregates for periods between scheduled meetings. The FOMC began stating its objectives as a specific percentage growth rate for each monetary aggregate from a month before the meeting to some future month. For instance, the objective for M1 adopted on October 6 , 1979 , was an annual growth rate of 4.50 percent from September to December 1979.

Although the FOMC continued to specify ranges for the federal funds rate, those ranges were widened significantly. For most periods, the range was 400 basis points, compared with ranges of 50 to 100 basis points under the procedure of targeting on the federal funds rate. These wide ranges on the federal funds rate played a minor role in the implementation of monetary policy under the new NBR operating procedure. In fact, on several occasions the FOMC widened its ranges between scheduled meetings when the rate threatened to move outside the previously established limits. On other occasions, the federal funds rate was allowed to move outside its range for short periods of time.

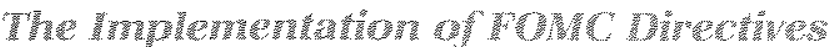

After each FOMC meeting, the Federal Reserve staff estimated the average level of total reserves that would be necessary to support the money stock desired by the FOMC. That average level was called the total re-

\footnotetext{
${ }^{7}$ Federal Reserve Bulletin (December 1979), p. 974 sSee Gilbert and Trebing (1981).
} 
serve path. Estimates of the total reserves path were based on (1) FOMC objectives for M1 and M2 and (2) estimates of the average reserve requirements on deposit liabilities in M1 and M2, currency, required reserves on liabilities of depository institutions not included in M1 or M2, and excess reserves. The staff generally re-estimated the total reserves path each week.

At each meeting, the FOMC made an assumption about the average level of borrowed reserves over the period until the next scheduled meeting. The FOMC's borrowings assumption was often near the average level of borrowings just before the meetings. The staff determined the level of NBR on which the Open Market Desk targeted open market operations /called the NBR path/ by subtracting the FOMC's borrowings assumption from the total reserves path.

The implementation of monetary policy under this operating procedure is illustrated in figure 2 . In contrast to the procedure illustrated in figure 1, the Open Market Desk would not increase the level of NBR in response to an increase in the demand for reserves; it might actually decrease NBR to keep total reserves near its path level."

Levels of total reserves and NBR on the horizontal axis refer to average levels for the weeks between FOMC meetings. The total reserves path is illustrated as $R^{*}$. The NBR path is $N_{1}$, since the FOMC set the borrowings assumption at $\mathrm{R}^{*}$ minus $\mathrm{N}_{1}$.

The demand curves for reserves represent the relationship between the federal funds rate and the aver age quantity of reserves demanded over a few weeks between FOMC meetings. Since the time period is a few weeks, required reserves are not predetermined but may be influenced by policy actions of the current period. A rise in the federal funds rate, for instance, might cause the quantity of money demanded to decline and, therefore, cause required reserves to decline. For these reasons, the demand curves have a flatter slope in figure 2 than in figure 1.

Total reserves would be at the path level $\mathrm{R}^{*}$ if the demand curve for reserves was $D_{1}$. From that initial position, consider the effects of an increase in the demand for reserves, illustrated by a shift in the demand curve to $\mathrm{D}_{2}$, which resulted from an increase in the demand for money. Total reserves would rise to $R_{1}$,

\footnotetext{
9Lindsey $(1982,1983,1984)$ describes how the procedure of targeting on NBP worked in practice by examining the timing of money growth relative to FOMC objectives, borrowed reserves, the federal funds rate and the discount rate.
}

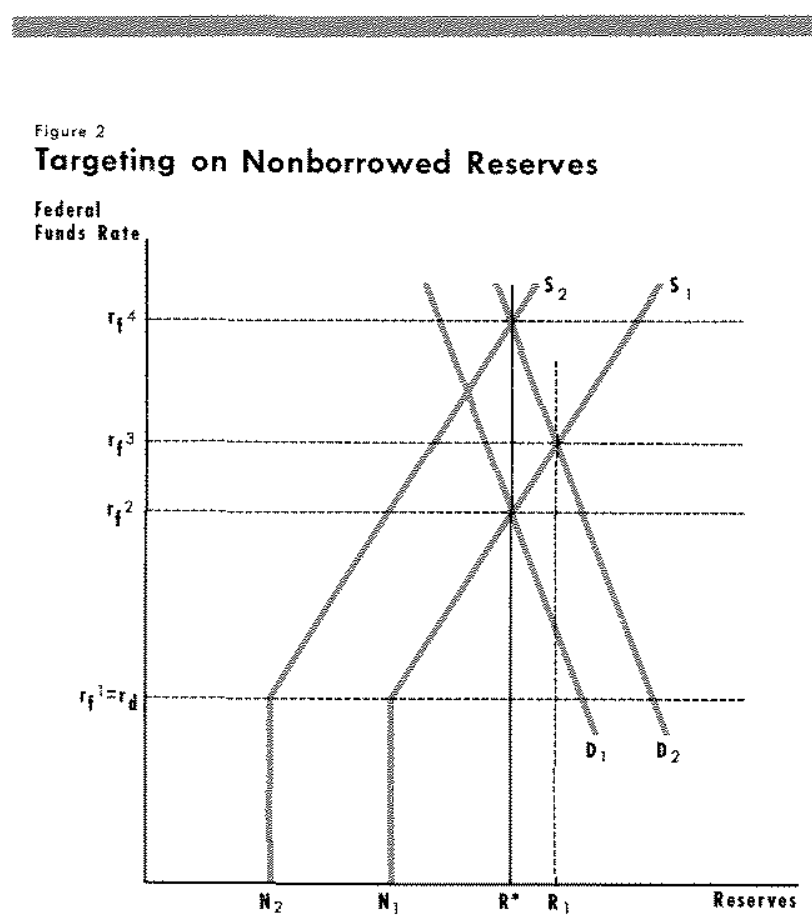

above the total reserves path, and the federal funds rate would rise from $r_{f}^{2}$ to $r_{r}^{3}$. Without any additiona policy actions, the money stock would exceed the FOMC's objectives because total reserves would be above the path level. For a given rise in the demand for reserves, however, the amount by which the money stock would exceed the FOMC objective would be smaller under this operating procedure than if the Open Market Desk had supplied the reserves neces sary to keep the federal funds rate unchanged at $n_{i}^{2}$.

During some periods between FOMC meetings, the Federal Reserve adjusted the level of the NBR path or the discount rate to reduce the deviations of the money stock from desired levels. "The Federal Reserve took those policy actions when the deviations ap peared to reflect more than a transitory movement ir the money demand schedule, perhaps due to : strengthening of aggregate spending."

Adjustments to the NBR path or discount rate be

\footnotetext{
10The Federal Reserve Bank of New York presents a detaled descrip tion of open market operations throughout each calendar year in the spring or summer issues of its Quarterly Review in the following year Those reports indicate several occasions on which the NBR targe or the discount rate were changed when the staff projected that tota reserves would deviate substantially from the path levels.

"See Lindsey (1983), p. 5.
} 
tween FOMC meetings were based on projections of total reserves. After each FOMC meeting, the staff estimated the actual level of total reserves over the weeks until the next meeting, as well as the total reserves path, which was based on FOMC objectives for money growth. The estimates of total reserves were based on projections of the actual (in contrast to the desired) money stock, average reserve requirements and excess reserves, given the existing discount rate and NBR path. A substantial deviation between the staff estimate of actual total reserves and the total reserves path indicated that additional adjustments to the discount rate or NBR path would be necessary to keep the money stock close to the FOMC objectives.

In the situation illustrated in figure 2 , the staff projects total reserves to be $R_{1}$, which is above the total reserves path $\left(\mathbf{R}^{*}\right)$. The policy action illustrated in figure 2 is a reduction in the NBR path relative to the total reserves path (an increase in the borrowings assumption). Total reserves are constrained to be at the path level by reducing the NBR path to $\mathrm{N}_{2}$, causing the federal funds rate to rise to $r_{\mathrm{r}}^{\mathrm{r}}$.

\section{The hole of he Orerating procedrure in He womey Suphly poras}

By adopting the NBR targeting procedure, the FOMC changed the basic relationship on which the money supply process was based. The prior procedure of targeting on the federal funds rate relied on a stable demand function for money. The second procedure of targeting on NBR relied on a relationship between reserves and the money stock. Path levels for total reserves and NBR were re-estimated weekly to incorporate the most current information available on the relationship between reserves and the money stock.

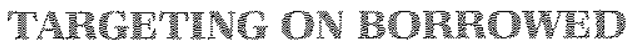 TESAFVES: OCTOWER 1982 TO

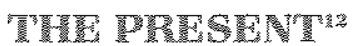

\section{The SHatement of PONC Objectives}

At a meeting in October 1982, the FOMC temporarily suspended its short-run objectives for M1. The event that precipitated the de-emphasis of $\mathrm{M1}$ was the maturing of a large volume of all-savers certificates in October 1982, which might have had a temporary effect on money demand. Also, movements of funds into

\footnotetext{
12This description of the procedure of targeting on borrowed reserves is based on Wallich (1984).
}

and out of MI were about to be affected in uncertain amounts by the scheduled introduction of a couple of monthly money-market-type accounts at banks and thrift institutions. The de-emphasis of M1 continued after these events because of an observed change in the relationship between the money stock and total spending in the economy.":

Suspending short-run objectives for M1 made it necessary to change the operating procedure for implementing monetary policy. The procedure of targeting NBR as described previously gave considerable weight to the FOMC's objective for M1, since a large proportion of required reserves are against the deposit liabilities in M1. The total reserves path could not be estimated on the basis of the FOMC's objectives for $\mathrm{M} 2$ and M3 without an assumption of tanget for M1 over the intermeeting period. The FOMC has resumed the practice of specifying short-run objectives for M1 but has not directed the Open Market Desk to resume use of the procedure of targeting NBR.

In place of the NBR procedure, the Federal Reserve adopted a procedure for largeting on borrowed reserves. At each meeting, the FOMC states its objectives for open market operations in terms of degrees of reserve restraint. The directive from the FOMC to the Open Market Desk calls for more restraint, less restraint, of for the degree of reserve restraint to be unchanged. In some directives, the FOMC also states conditions for changing the degree of reserve restraint in the period before the next scheduled meeting, such as deviation of the rate of money growth from desired rates or developments in the economy.

The Open Market Desk interprets the objectives of the FOMC for the degree of reserve restraint in terms of the average level of seasonal plus adjustment borrowings over the intermeeting period. ${ }^{24}$ More restraint would imply a higher level of borrowings and less

\footnotetext{
${ }^{13}$ See Axilrod (1985), pp. 18-19.

${ }^{14}$ See Wallich (1984), p. 26. Adjustment borrowings are short-term loans from Federal Reserve Banks to depository institutions to aid them in adjusting their reserves to required levels. Most institutions repay their adjustment borrowings within a few days. Seasonal borrowings are longer-ferm loans to depository institutions that have relatively strong seasonal patterns in their loan demand or deposits. Other borrowings are called extended credit, which is made avail able to institutions experiencing such severe financial difficulties that they have a hard time attracting funds from other sources. The target for botrowings under the current operating procedure is in ierms of the sum of seasonal plus adjustment borrowings. Extended credit is considered a relatively fixed supply of reserves, which is not as sensitive to the spread between the federal funds rate and the discount rate as seasonal and adjustment borrowings are. Extended credit is counted as part of nonborrowed reserves for purposes of implementing monetary policy under the current operating procedure.
} 


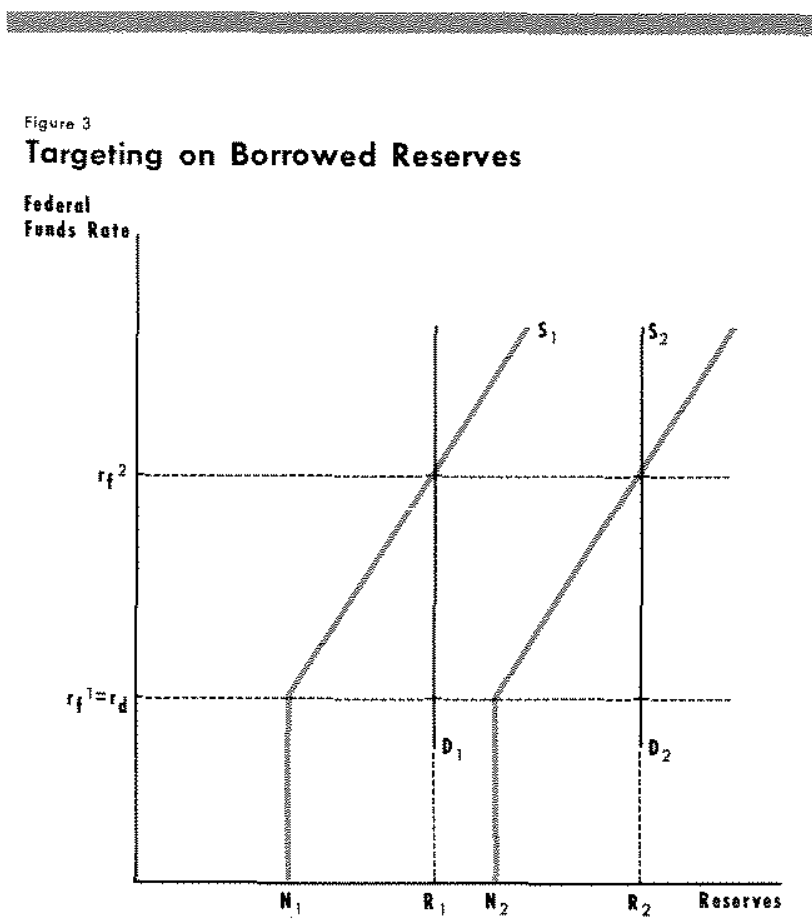

restraint a lower level of borrowings. The Open Market Desk changes its target level for borrowings between some FOMC meetings when the conditions for changing the degree of reserve restraint specified in the latest FOMC directive do occur.

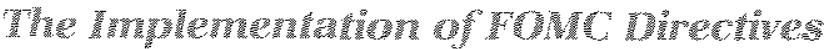

The amount of NBR supplied by the Open Market Desk under the current operating procedure depends on the target level for borrowed reserves and estimates of total reserves prepared by the Federal Reserve staff. The level of NBR to be supplied is determined by subtracting the target level for borrowed reserves from the staff estimate of total reserves.

The process of estimating total reserves depends on the system of reserve accounting in effect. Under lagged reserve requirements, in effect through January 1984, required reserves for each maintenance period were known by the beginning of the period. The estimate of total reserves for each period was derived by adding an estimate of excess reserves to the known level of required reserves.

Under contemporaneous reserve requirements, the reserve accounting system currently in effect, required reserves for each maintenance period are not known until after the end of the period. The staff esti- mates required reserves for each maintenance period revising the estimate several times during most peri ods. The target levels for NBR are adjusted by the samı dollar amounts as the revisions to estimates of re quired reserves.

The implementation of monetary policy under thi current operating procedure is illustrated in figure 3 This figure indicates that, by targeting on a given leve of borrowed reserves, the Open Market Desk tends tc eliminate any effect of shifts in the demand for re serves on the federal funds rate over a given reserv maintenance period.

Levels of total reserves and NBR on the horizonta axis of figure 3 refer to average levels over a two-wee] reserve maintenance period. The curves that repre sent the demand for reserves are drawn as vertica lines in figure 3 ; they are drawn as sloping downware to the right in figures 1 and 2 . This change does no imply that the demand for reserves is less interest elastic under the procedure of targeting on borrower reserves. The vertical demand curves reflect the war the demand for reserves is characterized under thi operating procedure, that is, as a fixed amount of re serves for each maintenance period.

Early in the maintenance period, the staff estimate total reserves at the level $\mathbf{R}_{1}$. With the target level fo borrowed reserves equal to $\mathbf{R}_{1}$ minus $N_{1}$, the Open Market Desk plans to supply NBR of $N_{1}$, which wouls yield an average federal funds rate of $\Gamma_{f}^{2}$. Suppose tha later in the period, the staff raises the estimate of tota reserves to $\mathbf{R}_{z}$. In response, the Open Market Des. raises its objective for $N B R$ to $N_{3}$, to keep $R_{z}$ minus $N$ equal to the original target level of $R_{1}$ minus $N_{7}$. Thi response to a rise in the demand for reserves woul keep the federal funds rate unchanged at $r_{i}^{2}$.

The increase in the estimate of total reserves from $F$ to $R_{2}$ may reflect a larger increase in the money stoc than desired by the FOMC. If the FOMC directive call for an increase in the degree of reserve restraint in th event of this undesired rise in the money stock, th Open Market Desk would increase its target level fo borrowings. The implications of an increase in th target for borrowed reserves can be illustrated by ret erence to figure 3 . In response to the increase in th estimate of total reserves from $R_{1}$ to $R_{2}$, the Open Mar ket Desk increases the supply of NBR above $\mathrm{N}_{1}$ but no as much as $\mathrm{N}_{2}$. In that case, the federal funds rat would rise above $r_{r}^{2}$. This response to an undesiret rise in the money stock is similar to the respons under the procedure of targeting on the federal fund rate when the Open Market Desk allowed the federa funds rate to rise to the top of its range. 


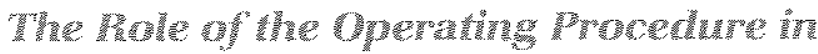

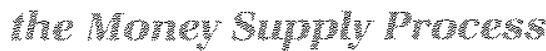

The current operating procedure has been described by one member of the FOMC as "an indirect method of influencing the funds rate and other shortterm rates which, in turn, affect the demand for money." Thus, like the procedure of targeting on the federal funds rate, the current method of controlling the money stock depends upon the influence of policy actions on interest rates and the assumption of a stable relationship between interest rates and the quantity of money demanded.

The similarity of the procedures of targeting on the fecteral funds rate and targeting on borrowed reserves is illustrated by examining the response of the Open Market Desk in supplying NBR to a shift in the demand for reserves. In targeting on borrowed reserves, the Open Market Desk responds to shifts in the demand for reserves in a manner similar to its response unde: the federal funds rate targeting procedure. The similarity is illustrated by comparing the response of the supply of NBR to a shift in demand for reserves in figures 1 and 3 . In both figures, the quantity of NBR supplied is increased in response to an increase in the demand for reserves, although the federal funds rate might be allowed to rise in response to an undesired rise in the money stock. Figure 2 indicates, in contrast, that under the NBR targeting procedure, the Open Market Desk keeps NBR unchanged or reduces them when there is an increase in the demand for reserves that reflects an increase in the demand for money.

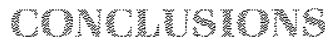

The Federal Reserve currently implements monetary policy by targeting open market operations on average levels of reserves borrowed from Federal Reserve Banks. This procedure, in effect since October 1982, has some features in common with the prior two ptocedures used for implementing monetary policy. Like the procedure of targeting on nonborrowed reserves, in effect from October 1979 until October 1982, the official range for the federal funds rate is several hundred basis points wide. Open market operations are not conducted with the objective of keeping the federal funds rate at a specific level, as they were un-

\footnotetext{
15Wallich (1984), p. 22.
}

der the procedure of targeting on the federal funds rate used for several years prior to October 1979.

The current procedure, however, has other similarithes to the procedure of targeting on the federal funds rate. There is no direct relationship between the objectives of the Federal Open Market Committee for the monetary aggregates and the supply of nonborrowed reserves, as there was under the procedure of targeting on nonborrowed reserves. Under the current procedure and that of targeting on the federal funds rate, the supply of nonborfowed reserves responds to shifts in the demand for reserves within a given reserve maintenance period in such a way that these shifts have little effect on the federal funds rate. Over longer periods, however, the federal funds rate might be allowed to move in the same direction as an undesired change in the money stock under both of those procedures.

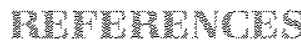

Axilrod, Stephen H. "U.S. Monetary Policy in Recent Years: An Overview," Federal Reserve Bulletin (January 1985), pp. 14-24.

Gilbert, R. Alton, and Michaet E. Trebing. "The FOMC in 1980: A Year of Reserve Targeting," this Review (Auglust/September 1981), pp. $2-22$

. "The New System of Contemporaneous Reserve Requirements," this Review (December 1982), pp. 3-7.

Holmes, Alan R., and Peter D. Sternlight. "The Implementation of Monetary Policy in 1976," Federal Reserve Bank of New York Quarterly Review (Spring 1977), pp. 37-49.

Lindsey, David E. "Recent Monetary Developments and Controversies," Brookings Papers on Economic Activity (January 1982), pp. 245-68.

. "Nonborrowed Reserve Targeting and Monetary Control" in Laurence $\mathrm{H}$. Meyer, ed., Improving Money Stock Control: Problems, Solutions, and Consequences, Economic Policy Conference Series, co-sponsored by the Center for the Study of American Business at Washington University and the Federal Reserve Bank of St. Louis (Kluwer-Nijhoff, 1983), pp. $3-41$.

"The Monetary Regime of the Federal Reserve System," presented at a conterence on Alternative Monetary Regimes, sponsored by the Ellis L. Phillips Foundation and Dartmouth College, August 22-24, 1984.

Lombra, Raymond E., and Raymond G. Torto. "The Strategy of Monetary Policy," Federal Reserve Bank of Richmond Economic Review (September/October 1975), pp. 3-14.

Wallich, Henry C. "Recent Techniques of Monetary Policy," Federal Reserve Bank of Kansas City Economic Review (May 1984), pp. $21-30$.

Wallich, Henry $C_{\text {., }}$ and Peter M. Keir. "The Role of Operating Guides in U.S. Monetary Policy: A Historical Review," Federal Reserve Bulletin (September 1979), pp. 679-90. 